\title{
MUSIC IN PHANTASTES AND LILITH BY GEORGE MACDONALD: THE PHENOMENON OF INTERMEDIALITY
}

\author{
(C) A. I. Samsonova \\ Lobachevsky State University of Nizhny Novgorod \\ 23 Gagarina prospekt, 603950, Nizhny Novgorod, Russia. \\ E-mail: trina_des@mail.ru
}

\begin{abstract}
Musical elements in the structure of G. MacDonald's Phantastes and Lilith in the context of the theory of intermediality are studied. The following musical elements are analyzed: motif of fairy world's music, images of music of nature, musical description of characters' voices, insertions of songs, interpretation of music as an art. These musical elements act as a characterization of topoi, landscape, characters, technique of stylistic imitation and means of rhythmic organization of narration, expression of author's point of view. The paper concludes that music in G. MacDonald's fairy romances is represented by means of intermedial imitation and intermedial thematization used for creation of full of sound fairy world and expression of Romantic view on music essence.
\end{abstract}

Keywords: intermediality, literature and music, imitation, thematization, interpretation, George MacDonald.

The relationship between literature and music is a common object of reflection and research for writers, musicians, literary critics, musicologists and philosophers. In modern science the synthesis of the arts is actively investigated in the context of the theory of intermediality. The term intermediality was coined by A. A. Hansen-Löve (Intermedialität und Intertextualität, 1983) [1]. The researcher interprets intermediality in semiotics aspect: the imposition of sign systems with additional semantic level as a result.

J. Schröter in his paper Discourses and Models of Intermediality presents four types of discourse on intermediality [2]. The first one is synthetic intermediality: a "fusion" of different media to supermedia, a model with roots in the Wagnerian concept of Gesamtkunstwerk. The second type is formal (or transmedial) intermediality: a concept based on formal structures not "specific" to one medium but found in different media. The third type is transformational intermediality: a model centered around the representation of one medium through another medium. And the fourth type is ontological intermediality: a model suggesting that media always already exist in relation to other media.

Literature and music relations are also discussed in the context of studies in intermediality. But previously in 1968 S. P. Scher in his work Verbal Music in German Literature described three ways of music representation in literature: 1) word music - poetic imitation of musical sound;2) formal and structural analogies to music; 3) verbal music - the rendering of subjective response to music or the suggestion the experience or effects of music [3].

W. Wolf in his essay Intermediality Revisited: Reflections on Word and Music Relations in the Context of a General Typology of Intermediality (dedicated to S. P. Scher) defines intermediality in both narrow and broad ways. Intermediality in the narrow sense (intracompositional intermediality) is "direct or indirect participation of more than one medium of communication in the signification and/or semiotic structure of a work or semiotic complex, an involvement that must be verifiable within this semiotic entity" [4, p. 17]. Intermediality in the broad sense (extracompositional intermediality) is "any transgression of boundaries between conventionally distinct media of com- 
munication" [4, p. 17]. W. Wolf describes intermedial reference as a variant of intracompositional intermediality. This form of intermediality operates exclusively on the basis of the signifiers of the dominant "source" medium and can incorporate only signifiers of another medium which become a part of the source medium. The decoding of intermedial reference is part of the signification of the work in which such references occur and is therefore a requisite for an understanding of the work. Intermedial reference falls into two subforms. The first one is explicit reference (or intermedial thematization) which is present whenever another medium (or a work produced in another medi$\mathrm{um}$ ) is mentioned or discussed in a text. The second subform is implicit reference (or intermedial imitation) in which the signifiers of the work and/or its structure are affected by the non-dominant medium, since they appear to imitate its quality or structure.

There is no unified approach to definition of intermediality and, in particular, to interpretation of literature and music relations in modern science. But according to the number of researches these problems are of current importance.

George MacDonald was a Scottish priest and writer of the 19th century. Known particularly for his fairy tales and fantasy novels, he inspired many authors, such as C. S. Lewis, J. R. R. Tolkien and L. Carroll. G. MacDonald's fiction is characterized by integration of musical elements. His creative activity represents a bright example of author's intension to use interaction of different art forms for various purposes. G. MacDonald was always keen on music. He organized the musical theatre with his family and often played the lead roles.

The great role in formation of G. MacDonald's views on music was played by German Romanticism ideas. Music was interpreted by romanticists as a secret language of nature, as an intimate essence of art, religion, love, speech. E. T. A. Hoffman called music "the most romantic of all the arts since its only subject-matter is infinity; the mysterious Sanskrit of nature, translated into sound that fills the human breast with infinite yearning; and only through it can they perceive the sublime song of - trees, flowers, animals, stones, water" [5, p. 94]. The life and the aesthetic views of Novalis inspired G. MacDonald deeply, especially his interpretation of fairy tale and dream. G. MacDonald translated Novalis' Spiritual Songs and Hymns to the Night into English and often quoted the German writer in his works.

Fairy romances Phantastes and Lilith by G. MacDonald include the set of musical elements and can be considered in the context of the theory of intermediality. There are following musical elements: motif of fairy world's music, images of music of nature, musical description of characters' voices, insertions of songs, interpretation of music as an art.

Two worlds, human and fairy, are represented in both Phantastes and Lilith. Fairy world is characterized by peculiar musicality, and the protagonist getting from one world to another feels it: "And at the moment, some strange melodious bird took up its song, and sang, not an ordinary birdsong, with constant repetitions of the same melody, but what sounded like a continuous strain, in which one thought was expressed, deepening in intensity as evolved in progress" [6, p. 69].

Gradually the protagonist becomes a part of fairy world joining its secrets, including music. In Phantastes having appeared in Fairy Land Anodos feels a strong impulse to sing: "It seemed as if some one else was singing a song in my soul, which wanted to come forth at my lips, imbodied in my breath" [6, p. 109]. Like Orpheus he brings marble lady back to life, like a minstrel he sings about glorious deeds of the knights.

In Lilith spaces of two worlds overlap one another and Vane the protagonist learns to feel both worlds at the same tame: "There! I smell Grieg's Wedding March in the quiver of those rose-petals!"- 
"I went to the rose-bush and listened hard, but could not hear the thinnest ghost of a sound; I only smelt something I had never before smelt in any rose. It was still rose-odour, but with a difference, caused, I suppose, by the Wedding March" [7, p. 24]. Also the moment of character's awakening for the true life is marked by golden cock's sing: "Far away - as in the heart of an æonian silence, I heard the clear jubilant outcry of the golden throat. It hurled defiance at death and the dark; sang infinite hope, and coming calm" [7, p. 258]. The idea of New Jerusalem sacral revival has a musical component: "Often would some bird, lovely in plumage and form, light upon one of them, sing a song of what was coming, and fly away" [7, p. 264].

According to the romanticists' pantheistic conception, the world around is a sounding world. The nature in G. MacDonald's works has also a musical description. Water seems to be the most musical element. "I would suddenly hear it [rivulet] again, singing, sometimes far away to my right or left, amongst new rocks, over which it made new cataracts of watery melodies" [6, p. 67]. "I heard below me many waters, playing broken airs and ethereal harmonies with the stones of their buried channels. Loveliest chaos of music-stuff the harp aquarian kept sending up to my ears! What might not a Händel have done with that ever-recurring gurgle and bell-like drip, to the mingling and mutually destructive melodies their common refrain!" [7, p. 87]. "My heart swelled at the thought of the splendid tumult, where the waves danced revelling in helpless fall, to mass their music in one organroar below" [7, p. 87]. Air has a musical description too: "the translucent trembling of the hot air that rises, in a radiant summer noon, from the sun-baked ground, vibrant like the smitten chords of a musical instrument" [7, p. 17]. Talking to a traveler the forest sings too: "The leaves and branches above kept on the song which had sung me asleep; only now, to my mind, it sounded like a farewell and a speedwell" [6, p. 31].

Musical characterization of voice plays an important role in creation of character's portrait. In Phantastes the knight has "a full, deep, manly voice, but withal clear and melodious" [6, p. 176]. The beech-tree's voice seems to Anodos "a solution of all musical sounds" [6, p. 30]. The old woman's voice is "sweet as the voice of a tuneful maiden that singeth ever from very fulness of song" [6, p. 136]. She sings fate: "While she spun, she murmured a low strange song, to which the hum of the wheel made a kind of infinite symphony" [6, p. 143]. In Lilith Raven's wife (Eve) has "a low, rich, gentle voice. Treasures of immortal sound seemed to he buried in it" [7, p. 30]. Her image is sacralized by musical characterization of voice: "her song soared aloft, and seemed to come from the throat of a woman-angel" [7, p. 245]. Description of the Little One's voices becomes an additional means underlining their naturalness: "A sudden shouting of children, mingled with laughter clear and sweet as the music of a brook, startled me with delight" [7, p. 60].

Antagonists are identified by the characterization of their voices too. It is Alder-maiden's voice that makes Anodos feel in danger: "there was something either in the sound of the voice, although it seemed sweetness itself, or else in this yielding which awaited no gradation of gentle approaches, that did not vibrate harmoniously with the beat of my inward music" [6, p. 45]. Lilith's voice is characterized by the motif of death: "with the voice of a dull echo from a sepulcher" [7, p. 208]. "Then the seeming corpse opened its mouth and answered, its words appearing to frame themselves of something else than sound" [7, p. 215].

Romanticism fiction (by Novalis, L. Tieck, C. Brentano) often includes insertions of poems and songs aimed "to get the sound, to awake it somewhere in the depth of depicted things and to light it from the inside in this way" [8, p. 33]. There are such insertions in G. MacDonald's works too. The songs added in the text have special meaning and organize it by rhythm. In Phantastes songs are of- 
ten presented as an element of ritual and stylized as certain folklore genre. So flower fairies sing a funeral song to Snowdrop, beech-tree sing a charm to Anodos, Anodos' songs like magic spells bring marble lady back to life, priests sing during sacrifice ceremony. F. Soto describes Phantastes as "an imaginative yet thorough, literary mythic-religious underground adventure into the very heart of ancient rituals and beliefs" [9, p. 25].

G. MacDonald's interpretation of music as an art is also represented in his works. In Phantastes the author makes very wise observation on music's nature: "It sounded like a welcome already overshadowed with the coming farewell. As in all sweetest music, a tinge of sadness was in every note" [6, p. 69]. There is an allegorical statement about fantasy essence and creativity nature in Lilith: "Say rather," suggests Hope, "thy brain was the violin whence it issued, and the fever in thy blood the bow that drew it forth" [7, p. 269].

So music in Phantastes and Lilith by G. MacDonald is presented in different forms and functions. The pointed out musical elements act as a characterization of topoi, landscape, characters, technique of stylistic imitation and means of rhythmic organization of narration, expression of author's point of view.

The integration of musical elements in literature as a phenomenon of intermediality plays a great role in G. MacDonald's creative activity. According to S. P. Scher's typology, the lead form of music representation in G. MacDonald's fairy romances is verbal music at which the specific of sounding and perception of nature music, character's voices, song melodies is rendered by verbal means. According to W. Wolf's theory, this form of music representation belongs to intermedial imitation. Other musical elements in G. MacDonald's fairy romances - the motif of fairy world's music and the interpretation of music as an art - are directly connected with the author's aesthetic views, with Romantic idea of existence panmusicality. In the context of the theory of intermediality this form of music representation belongs to intermedial thematization.

To sum up, music in G. MacDonald's Phantastes and Lilith is represented by means of intermedial imitation and intermedial thematization used for creation of full of sound fairy world and expression of Romantic view on music essence.

\section{REFERENCES}

1. Hansen-Löve A. Intermedialität und Intertextualität. Probleme der Korrelation von Wort- und Bildkunst - Am Beispiel der russischen Moderne // Dialog der Texte. Hamburger Kolloquium zur Intertextualität. Wien, 1983. S. 291-360.

2. Schröter J. Discourses and Models of Intermediality // CLCWeb: Comparative Literature and Culture. 2011. Vol. 13. Iss. 3. URL: http://dx.doi.org/10.7771/1481-4374.1790

3. Scher S. P. Verbal Music in German Literature. New Haven: Yale University Press, 1968.

4. Wolf W. Intermediality Revisited: Reflections on Word and Music Relations in the Context of a General Typology of Intermediality // Word and Music Studies. Amsterdam: Rodopi, 2002. Pp. 13-34.

5. E. T. A. Hoffmann's Musical Writings: Kreisleriana; The Poet and the Composer; Music Criticism / Ed. D. Charlton. Cambridge: Cambridge University Press, 2004.

6. MacDonald G. Phantastes. Hazleton, PA: The Electronic Classic Series Publication, 2012.

7. MacDonald G. Lilith. Hazleton, PA: The Electronic Classic Series Publication, 2012.

8. Berkovskiy N.Ya. Romantizm v Germanii [Romanticism in Germany]. Leningrad: Khud. lit., 1973.

9. Soto F. Chthonic Aspects of MacDonald's Phantastes: From the Rising of the Goddess to the Anodos of Anodos // North Wind, 2000. No. 19. Pp. 19-49. 


\section{МУЗЫКА В РОМАНАХ «ФАНТАСТЕС» И «ЛИЛИТ» ДЖОРДЖА МАКДОНАЛЬДА: ФЕНОМЕН ИНТЕРМЕДИАЛЬНОСТИ}

\section{(C) А. И. Самсонова}

Нижегородский государственный университет

Россия, 603950 г. Нижний Новгород, проспект Гагарина, 23.

E-mail: trina_des@mail.ru

В статье исследуются музыкальные элементы в структуре романов Дж. Макдональда «Фантастес» и «Лилит» в контексте теории интермедиальности. Анализируются следующие музыкальные элементы: мотив музыки волшебного мира, описание музыки природы, музыкальная характеристика голосов персонажей, песенные вставки, интерпретация музыки как искусства. Выделенные музыкальные элементы выступают как средство характеристики топосов, пейзажа, персонажей, как прием стилистического подражания и способ ритмической организации повествования, как выражение авторской позиции. Сделан вывод о том, что музыка в указанных романах Дж. Макдональда представлена посредством интермедиальной имитации и интермедиальной тематизации, которые автор использует для создания насыщенного звучанием волшебного мира и выражения романтического взгляда на сущность музыки.

Ключевые слова: интермедиальность, литература и музыка, имитация, тематизация, интерпретация, Джордж Макдональд.

Просьба ссылаться на эту работу как: Самсонова А. И. Музыка в романах «Фантастес» и «Лилит» Джорджа Макдональда: феномен интермедиальности // Российский гуманитарный журнал. 2014. Т. 3. №1. С. 16-20. 